\title{
UNESCO Strategy and Digital Policies for Teacher Training: The Deconstruction of Innovation in Spain
}

\section{Belén Espejo Villar $₫$, Luján Lázaro Herrero @ and Gabriel Álvarez-López $『$}

Department of Theory and History of Education, University of Salamanca, Spain

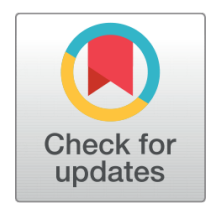

\section{Received 2021-06-23 \\ Revised 2021-06-29 \\ Accepted 2021-11-05 \\ Published 2022-01-15}

Corresponding Author

L. Belén Espejo Villar,

Ibev@usal.es

Facultad de Educación. Paseo de Canalejas, 169, 37001, Salamanca, Spain.

DOI https://doi.org/10.7821/ naer.2022.1.812

Pages: 15-30

Funding: Ministry of Science, Innovation and Universities,

Spain

(Award:PGC2018-097884-B-I00);

Regional Government of Castilla y León, Spain

(Award:SA038G19)

Distributed under

CC BY-NC 4.0

Copyright: ( ) The Author(s)

\section{OPEN ACCESS}

\section{ABSTRACT}

This paper examines initial teacher training policies in the context of youth digitalisation. Based on international ICT competency frameworks for teachers (UNESCO, 2008, 2019) and information literacy, MIL (UNESCO, 2011), we analyse how Spanish (public and private) universities represent digital innovation, and the identity practices of young people, linked to hyperconnectivity. Focusing on initial training received by future secondary teachers, the sample was selected according to the criteria of non-presential learning (online, distance, blended) applied in the teacher training process. Results confirm ongoing deficiencies in critical teacher digitalisation management, highlighting certain asymmetries between the categories constructed. Data reveals the prevalence of intervention more geared towards formal knowledge than towards decoding digital grammar (which is how digitalisation is used in education). The paper concludes by advocating convergence strategies as a circular mechanism that must underpin all teacher training policies in the age of hyperconnectivity.

\section{Keywords TEACHER, TRAINING, INNOVATION, TECHNOLOGICAL} EDUCATION, UNESCO

\section{INTRODUCTION}

The immersion of digital culture in education is one of the main pillars of teaching innovation as indicated in recent literature on digital education (Mace, 2020; Mahlow \& Hediger, 2019; Monteiro \& Leite, 2021; Morris \& Rohs, 2021; Pangrazio \& Sefton-Green, 2021; Sancho-Gil, Rivera-Vargas, \& Miño-Puigcercós, 2020; Williamson, 2019). This is innovation which, according to Marcelo and Vaillant (2018), must be disruptive due to the commitment acquired to ensure the principles of accessibility, quality and improvement in changing contexts. The leading role of digital technology as an element in breaking away from traditional models has been paramount in non-presential contexts, placing training spaces, digital skills and learning methods at the centre of an academic and political debate that has brought teacher training and the potential of digital technology back to the centre of educational research (Dujo, Vlieghe, Muñoz-Rodríguez, \& Martín-Lucas, 2021; Lee \& Trimi, 2021; Leite, 2019). 
Incorporating new ways of digital learning (Bergdahl, Nouri, \& Fors, 2020; Eurydice, 2019) and opening up other training spaces (virtual campuses) is not new in teacher training, as presented in research conducted by various authors (Cabero, 2004; Cabero \& Martínez, 2019; Espejo-Villar, Lázaro-Herrero, \& Álvarez López, 2020) based on theoretical and practical developments in perceptions, uses and approaches to problems. Technological skills have thus been introduced into the teacher training system both at the outset and in ongoing education cycles, according to work related to educational success and teaching policies (OECD, 2018; Sung, Chang, \& Liu, 2016).

In the context of in-service training, strategic frameworks at European (Comission, 2017; European Comission, 2020; European Parliament, 2018; Ferrari, 2013; Redecker \& Punie, 2017) and national level (INTEF, 2013), among others, have favoured the design and implementation of specific ICT plans for active teachers (Plan de cultura digital en la escuela (Digital Culture at School Plan), 2013, Marco estratégico de desarrollo profesional docente (Strategic Framework for Professional Teacher Development), 2013, Educa en digital (Educate in Digital), 2020), for the purpose of responding to teacher digitalisation competency demands and improving school learning; the latter is one of the greatest challenges facing education systems according to the OECD (2018). Despite this, a command of ICT skills geared toward teaching is still pending in teacher training in OECD countries, the European Union and Spain, as highlighted in the TALIS report (OECD, 2019).

The case of ICT policies for initial training is paradigmatic due to a teacher's role in producing digital culture, and the resulting pedagogical effects. Academic literature on this issue (Börnert-Ringleb, Casale, \& Hillenbrand, 2021; Prendes, Castañeda, \& Gutiérrez, 2010) has highlighted the motivational impact that digital innovation can have on learning and the educational capital it can generate.

Nevertheless, research on initial teacher training policies has not responded to some of the questions posed on how it overlaps with digital technology. A specific example is the differential and segregating consequences that teachers' manner of using digitalisation in education have on students; training received by teachers underlies this and it represents a gap that generates inequalities that are increasingly evident (Warschauer \& Matuchniak, 2010, cited by Dussel, 2012). Dussel (2012) focuses on the field of teacher learning and expresses this through the knowledge teachers produce as prosumer agents (producers of learning experiences and consumers of training) of the educational process. However, we do not know which training parameters are the basis for developing this new digital culture and how teachers drive it. In this race towards digital technology we have also forgotten that the grammar of digitalisation (understood as the configuration and development of digitalisation) not only affects teachers, but also constitutes a capital construct in the legitimisation of young people's identity practices.

Recent studies (Forbes, 2017; Goriunova, 2019; Muñoz-Rodríguez, Torrijos-Fincias, Serrate-González, \& Murciano-Hueso, 2020) focus their research on how youth identities operate, and their link to the training of teachers, who are conceived as essential agents in building the digital identity of young people. Rethinking teaching practice as one element of the processes responsible for the digital humanisation of young people introduces a new 
aspect of interest in the study of policies that underpin initial teacher training, especially if we consider that the personal literacy of these students (no longer the personal literacy of primary education; however, the students' immaturity requires greater support) encloses sociability subjectivities and processes that take place in educational digital praxis.

This line of reflection thus forces us to examine the macroinstitutional coordinates referenced in the digitalisation of education policies by international bodies, especially UNESCO, which has been directing educational systems towards a digital culture for years $(2011,2019)$. As we will see below, this digitalisation strategy is developed in the ICT Competency Framework for Teachers (UNESCO, 2008, 2019) and is particularly specified in the UNESCO Media and Information Literacy (MIL) curriculum, which openly points towards the digital procedures and uses young people should employ, the significance of which must be directed by teachers.

As a whole, the connection and interaction of this strategy with digital school culture would create a new paradigm in this area, although, up to now, its fragmentation represents a structural contradiction and primarily a loss of meaning in teacher training, as verified in the recent declaration on La Educomunicación en España: Un reto urgente para la sociedad digital (Educommunication in Spain: An Urgent Challenge for the Digital Society) (Aguaded \& Marzal-Felici, 2021). Hence, this paper seeks to overcome the division of knowledge to date in the UNESCO strategy and advocate a relationship of interdependence in teacher training policies as part of digital innovation (UNESCO, 2020).

\section{THE UNESCO STRATEGY AND INITIAL TEACHER TRAINING: A NECESSARY HYBRIDISATION IN THE NEW DIGITAL ERA}

From the perspective of initial teacher training policies, we have verified that there is still great heterogeneity in European teaching models regarding access requirements, as well as in the organisation of training competency programmes (Egido, 2020). Paradoxically, the development of technological competencies has followed a somewhat different path in this teacher training context (Mishra \& Koehler, 2006), acquiring the same status of knowledge as other disciplinary areas such as pedagogical training, specialisation content or managing multicultural contexts, among others (OECD, 2018). Teacher training in technology has thus increased its curricular share among teachers as a whole, in both primary and secondary education, and in all countries (OECD countries, around 80\%; EU 81\%; and Spain 86\%) (OECD, 2019).

However, and despite progress made with a greater curricular presence of technology in training policies, teacher digital literacy is still far from a universal premise in schools (Castañeda, Salinas, \& Adell, 2020; UNESCO, 2008, 2019).

Institutionally, the emergence of an ICT competency framework for teachers (2008, 2019) first, and subsequently the MIL curriculum proposal (2011), have indeed set the foundations for digital operations, attempting to provide teachers with strategies to configure a digital identity to shape young people into 'collaborative, problem-solving, creative learners and innovative and engaged members of society' (UNESCO, 2019, p. 5) but the truth 
is that addressing the issue in terms of curriculum is fragmented, weakening the educational potential of digitalisation and hindering teaching developments. The disciplinary strength of MIL in the context of communication has been amply verified (Alcolea, Reig, \& Mancina, 2020), but now its connection with the ICT competency framework for teachers must be given visibility. Normalisation of youth digitalisation will depend on the capacity of institutions responsible for teacher training to bring this action plan together.

In terms of content, the ICT competency framework (Figure 1) includes 18 competencies organised into six areas of teaching practice (understanding ICT in education, curriculum and assessment, pedagogy, application of digital skills, organisation and administration, and teacher professional learning), and three levels of pedagogical use of ICTs by teachers (knowledge acquisition, knowledge deepening and knowledge creation).

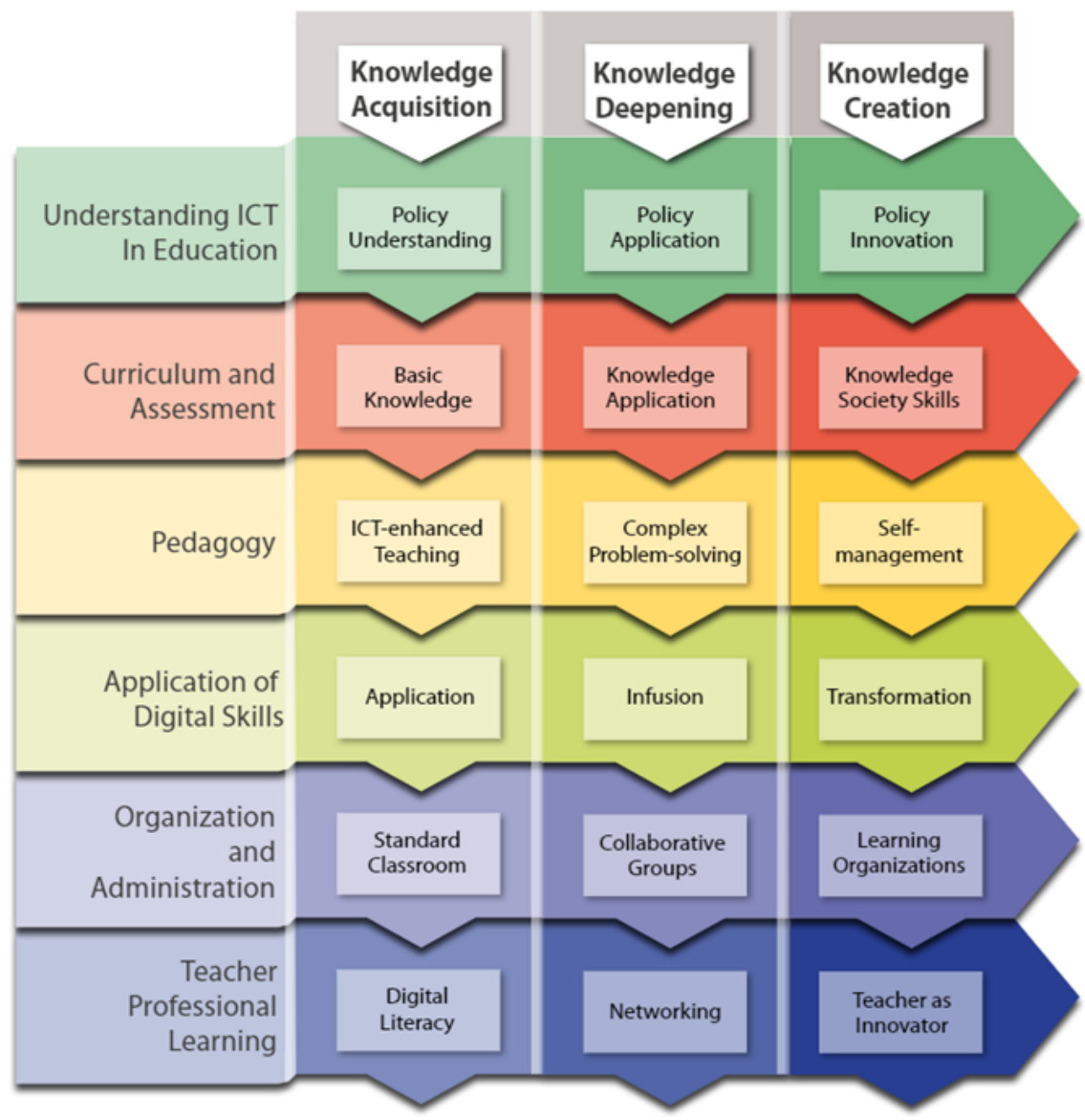

Figure 1 The UNESCO ICT Competency Framework for Teachers. Source: UNESCO, 2019, p. 8

Following this strategy, it is imperative to think about how digitalisation is represented conceptually and procedurally in teacher training. Research is required on the digital gram- 
mar containing innovation offered at other universities and we must define to what extent digital innovation is being conceived from the perspective of identity parameters for young people.

Are teachers receiving answers to hyperconnectivity problems in students aged 12 to 18 ? Have teachers received training on this responsibility? Outcomes from some research studies (Muñoz-Rodríguez et al., 2020) show that young people aged 16-18 exhibit more problematic (less time management, less self-regulation) use of mobile devices, which leads us to think that designing more critical education actions guided by teachers is a matter of urgency.

\section{RESEARCH APPROACH}

This paper is part of a broader research project that attempts to verify the role of political subjects in the digitalisation of education. One of the core areas of this research focuses on analysing how the digital aspect is being considered in school governance (UNESCO strategy) and in which grammatical keys digital literacy is defined in teacher training policies (Figure 2 ).

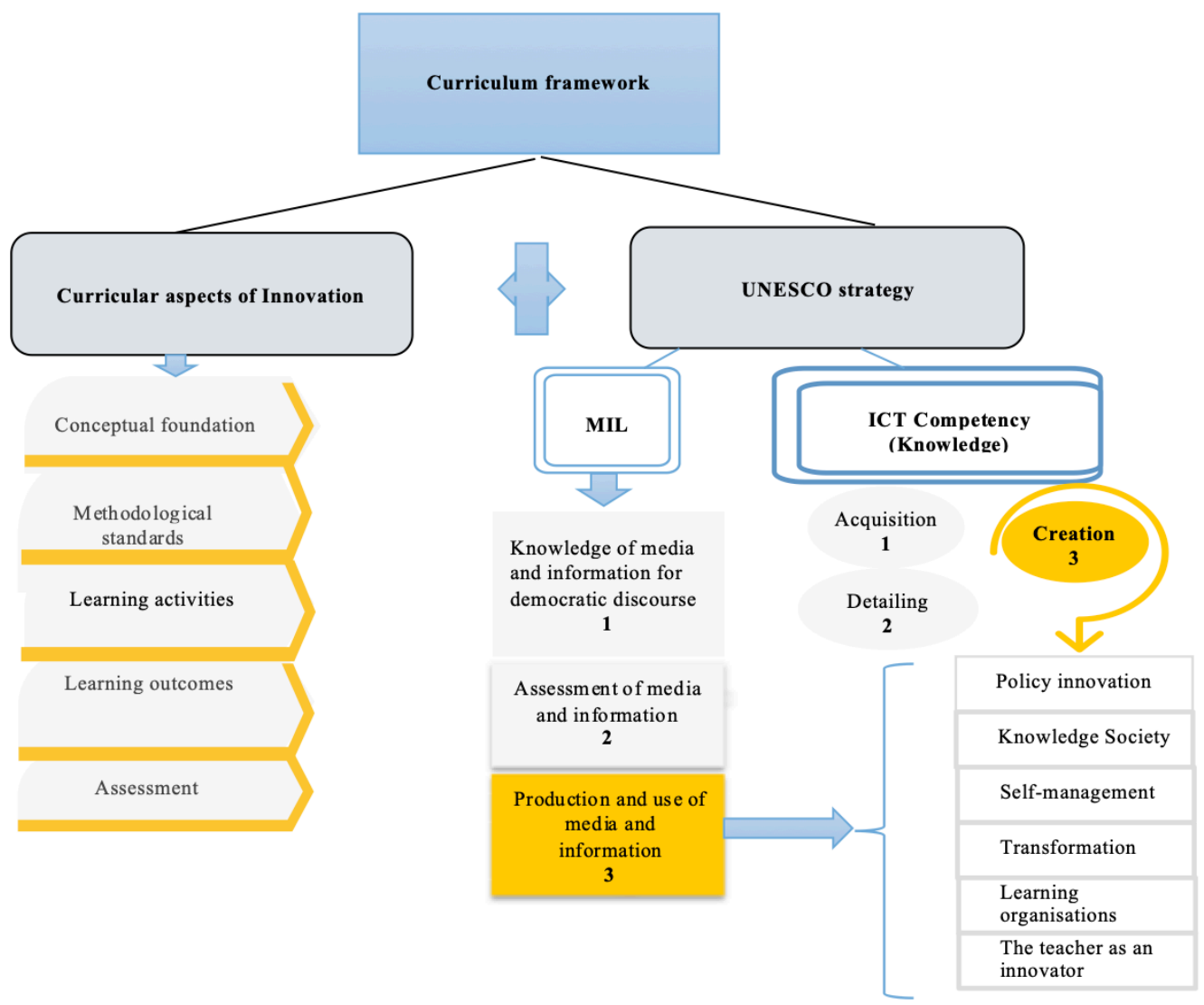

Figure 2 UNESCO strategy and innovation in teacher training. Source: Prepared by authors 
We start from the construct that increased digitalisation of education has become an element of the educational process, in which subjectivities (and personal cultures) accompanying these practices represent a central mechanism in shaping identity. Throughout this process we must understand that teachers have become its main exponents; however, how teaching staff are managing this duty is unknown. This analysis therefore has a dual purpose: on one hand, to understand how the digitalisation of education is being configured, included in the discipline of teaching innovation as a whole, and regulated in the institutional framework for initial training (Master's in Secondary Education Teacher Training etc.), for which we have focused on universities (public and private) offering training that is non-presential (online, distance, blended) (Table 1).

\begin{tabular}{|c|c|c|}
\hline \multicolumn{3}{|l|}{ Universities } \\
\hline University Oberta of Catalonia & Private & On-line \\
\hline University Pompeu Fabra & Public & On-line \\
\hline National University of Distance Education, UNED & Private & $\begin{array}{l}\text { Distance } \\
\text { Blended }\end{array}$ \\
\hline University Alfonso X el Sabio & Private & On-line \\
\hline University Camilo José Cela & Private & $\begin{array}{l}\text { Distance } \\
\text { Blended }\end{array}$ \\
\hline Catholic University San Antonio of Murcia & Private & Blended \\
\hline European University of Madrid & Private & Blended \\
\hline University Francisco of Vitoria & Private & $\begin{array}{l}\text { Presencial } \\
\text { On-line }\end{array}$ \\
\hline International University Isabel I of Castile & Private & $\begin{array}{l}\text { On-line } \\
\text { Distance }\end{array}$ \\
\hline International University of La Rioja & Private & On-line \\
\hline International University of Valencia & Private & On-line \\
\hline University of Mondragón & Private & $\begin{array}{l}\text { Blended } \\
\text { On-line }\end{array}$ \\
\hline University of Navarra & Private & $\begin{array}{l}\text { Blended } \\
\text { On-line }\end{array}$ \\
\hline University of Nebrija & Private & Blended \\
\hline Distance University of Madrid UDIMA & Private & Distance \\
\hline University of Vic & Private & Blended \\
\hline University San Pablo CEU & Private & Blended \\
\hline
\end{tabular}

Source: Prepared by authors

On the other hand, and in relation to the institutional dimension of training, we would like to understand the role of universities in projecting the UNESCO competency discourse (2008; 2019), and their ability to combine the international political agenda with digital culture in education.

This dual purpose is addressed by three research questions (Figure 3) so we can verify how teacher training overlaps externally with the approach of global models (UNESCO), and assess its response to configuring identity in young people, as well as intra-institutional development and future prospects. 


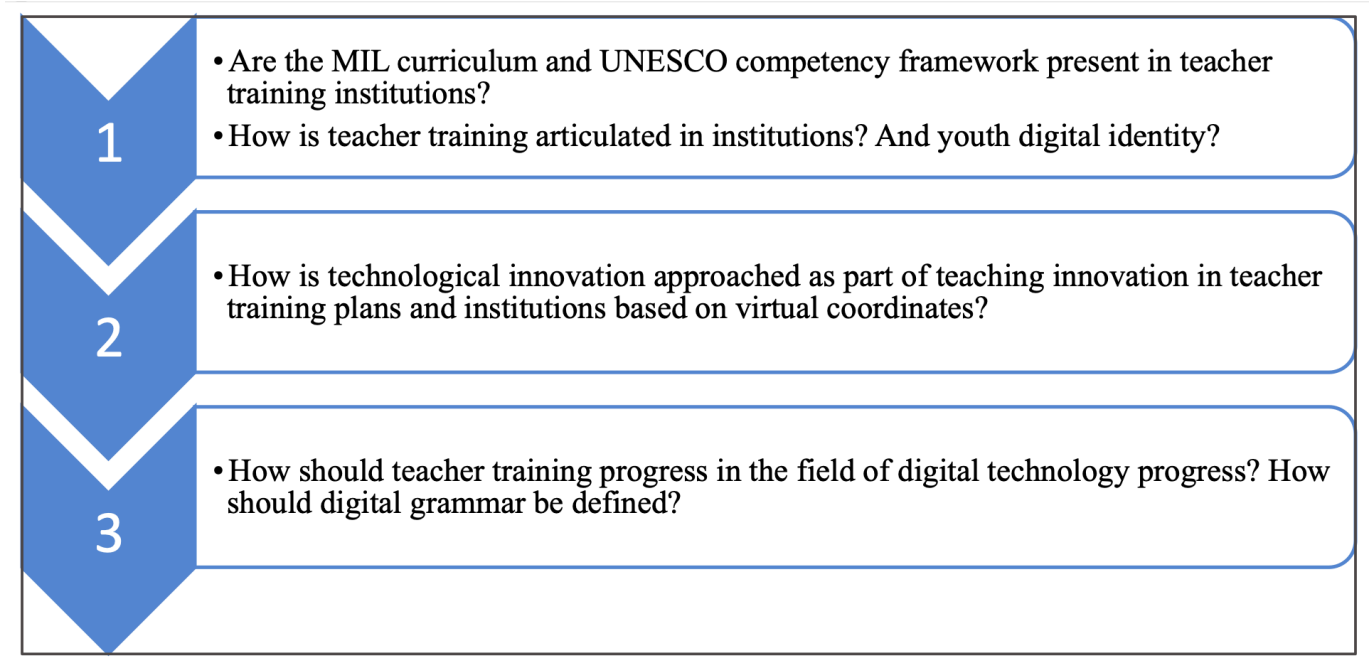

Figure 3 Mechanismand research questions. Source: Prepared by authors

\section{METHODOLOGY}

Master's courses were selected according to their teaching method (online, blended, distance), understanding that these courses favour digitalisation of training and innovation in the virtual approach to learning in the 2020-2021 academic year.

The analysis focused on the content of curriculum frameworks, conceived by many authors (Quesada-Serra, Rodríguez-Gómez, \& Ibarra-Sáiz, 2017; Zabalza-Beraza \& Zabalza-Cerdeiriña, 2010) as one of the main indicators of quality in the planning of content, methodological criteria and assessment of teachers. As indicated above, the subject selected was Innovation, present in the different specialities of the chosen universities. Analysis was therefore qualitative (Díaz-Herrera, 2018) in order to establish exploratory inferences between the curricular content of teaching frameworks (content, methodology and assessment) and how universities have adapted the competency and curricular tools provided by UNESCO in its ICT competency framework for teachers and the MIL curriculum, both described above (Figure 1).

Analysis units were compiled according to a grammatical approach to the content (Cáceres, 2003) as this study perspective enables us to understand the level of innovation present in teacher training policies, their level of affiliation to the standards set by UNESCO $(2011,2019)$ and/or their need for updating.

Taking the basic values through which educational innovation is planned as the point of study, we will attempt to examine whether future secondary education teachers (noncompulsory secondary education and vocational training) are trained in learning that incorporates the educational and critical logics of digital innovation and whether their training aims to facilitate the construction of identity (relationship and personal) of young people.

Analysis categories, or semantic fields according to Cáceres (2003), were formulated for each unit under study and in turn determined teacher training planning. Five categories 
were established: Conceptual Foundation, Methodological Standards, Learning Activities, Learning Outcomes, and Assessment. Codes were defined and reworked according to the ICT competency for teachers and MIL curriculum proposed by UNESCO $(2008,2011)$ shown in Figure 1. The categories and their respective codes aimed to examine the meaning of digitalisation in disciplinary innovation regulated in initial teacher training plans, and to analyse their link to youth sociability practices.

Categories were created according to the same guidelines for the two frameworks analysed (Table 2); the third level of informational knowledge was used in relation to the MIL curriculum framework (Production and use of media and information). The analysis also focused on the third level (Knowledge creation) of ICT competency for teachers. In both cases, the use of the last level of detail enabled us to establish greater interaction with the keys to youth digital identity.

Data on the areas of Policy and Vision (MIL), Understanding ICT in Education (ICT Competency) and Curriculum and Assessment (MIL and ICT Competency) were correlated in the Conceptual foundation analysis category in order to obtain information on two elements: firstly, related to the innovation message conveyed by the universities studied through the content formulated. This category aimed to verify whether the contents formulated are oriented towards the reflexive-theoretical (transformation of content, ethical aspects, control and security in the use of technologies, policy innovation), methodological (good practices, self-management, organisation of learning, innovation) and/or technological aspect (technical knowledge of innovation). On the other hand, the element related to the configuration of youth identity was associated with knowledge referring to self-management and self-regulation mechanisms.

The Methodological Standards category aimed to verify the disruptive nature of innovation by using methodological resources that legitimise students as active subjects and to generate transformative competencies. These are two major, identifiable methodological codes in the MIL curriculum and in ICT competency for teachers. We included the Pedagogy (MIL/ICT Competency), Organisation and Administration (MIL/ICT Competency), Application of Digital Skills (ICT Competency) and Teacher Professional Development (MIL) dimensions in this block.

Configuring youth identity was related to a methodology geared towards the social, personal and school function of digitalisation, as well as the cooperative dimension.

The category of Learning Activities was organised according to the integrating nature of technological resources, the use of open digital tools and how activities are expressed. Dimensions included in reference frameworks were: Application of Digital Skills (ICT Competency), Teacher Professional Learning (ICT Competency) and Teacher Professional Development (MIL).

Youth identity profile was related to: self-management, self-regulation mechanisms (adapted times) and creativity.

The category related to Learning Outcomes reflects all previous work. Its content was therefore divided into three sections: what they should know (cognitive plane), what they should know how to do (procedures, competencies), and the attitude with which 
Table 2 Categories and codes based on the MIL curriculum (UNESCO) and ICT Competency for Teachers (UNESCO, 2019). Source: Prepared by authors

\begin{tabular}{|c|c|c|}
\hline ICT codes & Categories & MIL codes \\
\hline $\begin{array}{l}\text { - Innovation content: Knowledge of ICT pol- } \\
\text { icy guidelines, changes (reinterpretation) of } \\
\text { the curriculum } \\
\text { - Digital identity content } \\
\text { - Knowledge of implications of digital uses }\end{array}$ & $\begin{array}{l}\text { - Conceptual foundation: } \\
\text { - Policy and vision / Understanding ICT in } \\
\text { education } \\
\text { - Curriculum and assessment }\end{array}$ & $\begin{array}{l}\text { - Innovation content: Teaching innovation mech- } \\
\text { anisms related to digitalisation, transformation of } \\
\text { knowledge, ethical, control and security aspects in } \\
\text { the use of technologies, pedagogical approach of } \\
\text { digitalisation innovation } \\
\text { - Digital identity content: Knowledge of implica- } \\
\text { tions of digital use }\end{array}$ \\
\hline $\begin{array}{l}\text { - Innovation content: Pedagogical alternatives } \\
\text { that legitimate the student as an active subject. } \\
\text { - Critical thinking and problem solving. } \\
\text { Flipped classroom. Cooperative learning } \\
\text { - Digital identity content } \\
\text { - Cooperation function/Staff-student }\end{array}$ & $\begin{array}{l}\text { - Methodological standards: } \\
\text { - Pedagogy } \\
\text { - Application of digital skills } \\
\text { - Organisation and administration }\end{array}$ & $\begin{array}{l}\text { - Pedagogical alternatives that legitimate the stu- } \\
\text { dent as an active subject } \\
\text { - Generating transformative competencies: Criti- } \\
\text { cal thinking and problem solving. } \\
\text { - Digital identity content: Cooperative function }\end{array}$ \\
\hline $\begin{array}{l}\text { - Application of digital skills for learning } \\
\text { - Combination of digital resources and tools. } \\
\text { - Use of software packages } \\
\text { - Digital identity content: Problem solving }\end{array}$ & $\begin{array}{l}\text { - Learning activities: } \\
\text { - Application of digital skills } \\
\text { - Teacher professional learning/Professional } \\
\text { development }\end{array}$ & $\begin{array}{l}\text { - Integration of technological resources } \\
\text { - Open digital tools: Collaborative problem solv- } \\
\text { ing } \\
\text { - Level of expression of activities } \\
\text { - Digital identity content: Self-management, self- } \\
\text { regulation mechanisms (adapted times) }\end{array}$ \\
\hline $\begin{array}{l}\text { - Cognitive plane: Knowledge of educational } \\
\text { platforms } \\
\text { - Procedural-competency plane: Experiment } \\
\text { and share ongoing training practices. Dis- } \\
\text { tribute educational resources } \\
\text { - Emotional plane: Generate critical thinking, } \\
\text { device use codes }\end{array}$ & $\begin{array}{l}\text { - Learning outcomes: } \\
\text { - Application of digital skills } \\
\text { - Teacher professional learning } \\
\text { - Pedagogy } \\
\text { - Policy and vision / Understanding ICT in } \\
\text { education } \\
\text { - Curriculum and assessment }\end{array}$ & $\begin{array}{l}\text { - Cognitive plane: Knowledge of educational plat- } \\
\text { forms, adaptation to education policies, assess- } \\
\text { ment of public-private alliances } \\
\text { - Procedural-competency plane: Preparation of } \\
\text { materials and programmes on speciality study } \\
\text { (change of indicators). Relationship with global } \\
\text { issues, social problems. Shared learning (share } \\
\text { materials prepared individually and/or in group). } \\
\text { Joint and collaborative intra-centre and inter- } \\
\text { centre planning } \\
\text { - Emotional plane: Identify negligent device use } \\
\text { attitudes and practices }\end{array}$ \\
\hline $\begin{array}{l}\text { - Use of tools that entail application and reflec- } \\
\text { tion: Diary, blog, forums } \\
\text { - Assess the creation of digital tools } \\
\text { - Digital identity content: Share resources, } \\
\text { Collaborative assessment }\end{array}$ & $\begin{array}{l}\text { - Assessment Curriculum and assessment } \\
\text { - Application of digital skills } \\
\text { - Teacher professional learning/Professional } \\
\text { development }\end{array}$ & $\begin{array}{l}\text { - Assess professional practices } \\
\text { - Digital identity content: Use and foundation } \\
\text { of digital resources (study, selection and creation) } \\
\text { adapted to groups and problems }\end{array}$ \\
\hline
\end{tabular}

they should do it to become an innovative teacher. This category included practically all the dimensions of the UNESCO frameworks (MIL and ICT Competency for Teachers): Application of Digital Skills, Teacher Professional Learning, Teacher Professional Development, Pedagogy, Policy and Vision, Understanding ICT in Education, and Curriculum and Assessment.

The assessment included the UNESCO dimensions that activate learning progress by future teachers: Curriculum and Assessment, Application of Digital Skills, Teacher Professional Learning and Professional Teacher Development, and which include aspects related to both digital innovation and youth identity culture. 


\section{RESULTS}

Overall, results highlight the difficulty in converting the digitalisation of education into an innovative teaching model. This is surprising as this analysis studies the university context and focuses on non-presential learning.

Figure 4 includes data analysed by category and obtained according to the level of creation or production of knowledge, in terms of subjectivities (what for, who learning digitalisation targets), an idea used by Hernández-Hernández and Sancho-Gil (2020) to reference the relationship function required of innovative learning by future teachers (indirect narrative).

Graphically, the results offer three blocks ranging from a low level of digital and identity innovation (formal creation) to another level showing the conceptual meaning of digital culture (narrative creation) and, finally, the differentiated level of this substantive figure. The outcomes of this level would be desirable digital and identity innovation (indirect narrative creation).

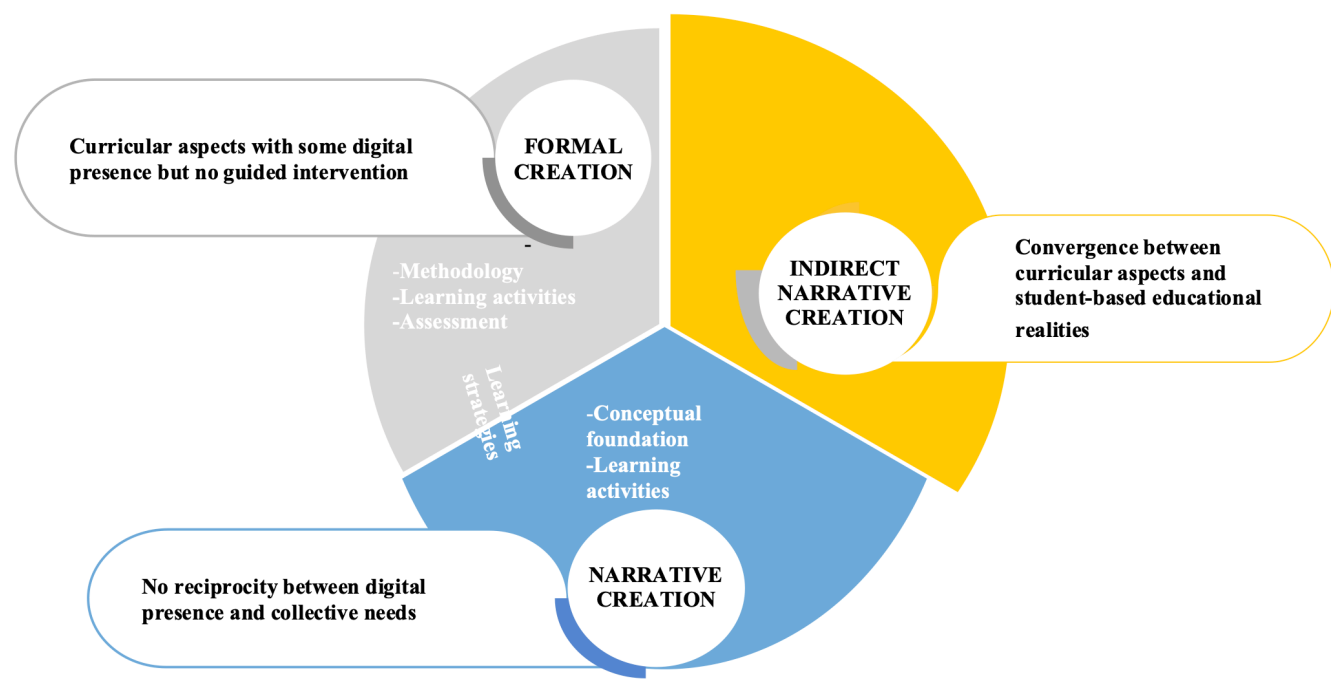

Figure 4 Synthesis of results. Source: Prepared by authors

\subsection{Conceptual Foundation. Reductionist Convergences of Innovation}

Following this idea, content analysis reflects the following issues. Knowledge given to future teachers can be grouped into three blocks: the theoretical-reflexive block (on digitalisation and the role of teacher and school); the methodological block (with notable proposals such as gamification and the flipped classroom -although none require the use of digital tools or a digital approach- and to a lesser extent mobile learning or the TPACK model); and the technology block (on specific software tools -applications- to develop teaching/learning processes, especially when implementing activities and assessment tools). After reviewing the content, only one of the universities studied includes content on cybersecurity. 
Regarding the UNESCO strategy, the content of the Master's degrees analysed are related to all aspects of the ICT Competency for Teachers framework and the MIL curriculum, particularly: Understanding ICT in Education (theoretical-reflexive block), Curriculum and Assessment (methodological and technology blocks), Organisation and Administration (methodological and technology blocks), and Teacher Professional Learning (theoreticalreflexive block). As for the levels proposed in the UNESCO strategy, depending on the level of abstraction of reflection and depth of teacher study, content can fall under any of the levels established by UNESCO; although it is true that the content necessary to create suitable digital spaces to develop youth digital identity is more ambitious than that proposed by the Master's programmes analysed.

Therefore, in the interpretative framework of the third level of use of ICTs, innovative subject content falls under the second level (narrative creation) as this content allows the future teacher to understand, justify and propose educational uses of digital tools without achieving indirect narrative creation (level 3), which would entail generating instruments and strategies adapted to the needs of the subjects and students.

This limitation in addressing content allows us to glimpse a reductionist, outdated approach to innovation and the digitalisation of education; an obsolete approach that does not respond to the training and digital identity needs of students. Content that addresses socio-critical, neuro-educational, philosophical, political and didactic perspectives, which are important in order for future teacher training to respond to social requirements, has yet to be incorporated.

\subsection{Methodology and Learning Activities. Mere Digital Instrumentalization}

If we pause to focus on the methodological issues proposed, we must highlight how the training process revolves around the standardisation of student self-learning, adapting to their capacities, needs and interests. Therefore, both self-learning and learning (guided, collaborative, reflexive, practical, critical) are the pillars that underpin this teaching. This design opts for the use of active methodologies - not always linked to the use of digital toolsincluding: Project-Based Learning (PBL), Flipped Classroom, Problem- and ChallengeBased Learning, Gamification and Case Studies, among others. These methodologies are directly contemplated in the pedagogical approaches of the Pedagogy in Teaching and Learning dimension of the MIL curriculum framework (UNESCO, 2011) proposed as learning methods. This type of active teaching is also in line with the UNESCO strategy (2008; 2019), although we can see that the lines set do not correspond to the concept of disruptive innovation, capable of affecting the entire educational context. Despite their virtual format, we understand that these methodological lines lie at the level of formal innovation as the manner of structuring the learning process continues to fall on traditional and linear levels where technology is merely instrumental, with no transformative consequences on the subjectivity and digital knowledge of the student (future teacher) who, in turn, is a key agent in constructing the digital identity of young learners. 
In direct relation to the methodological approach, assessing the activities proposed leads us to classify them, based on two variables: activities typical of a methodology combining traditional teaching strategies with strategies in which the student takes part in their own learning process, and activities stemming from the use of pedagogical digital technology. The first group repeats the tone of using Master's classes and/or lectures to develop content. In addition, tasks ranged from seminars, debates, simulations, critical thinking activities, and educational proposals, to scheduling material readings, reports or preparing educational resources. One common activity involving the use of educational technological tools is the forum, as well as the use of videos and creating clips in addition to tools such as Wikis, Kahoot or Socrative for use in the classroom. Some activities are also designed to use Web 2.0 and 3.0 tools or create digital portfolios. Activities requiring a level of knowledge creation (level 3) are programmed to a lesser extent based on strategies for self-management and experimentation. We can therefore affirm that future teachers receive training that enables them to reach levels of digital literacy (formal creation), with a slight attempt to offer more in-depth training (narrative creation) in their use but which would not reach levels of transformative competencies in terms of acquiring exploration, integration and improvisation skills (indirect narrative creation). So we would say that training provides teachers with competencies of knowledge and use of educational digital tools, but is far from reaching an indirect narrative level from which to teach in changing environments that are not preestablished and require content and also experience, discovery and relationship strategies. The teacher will not be capable of awakening experimentation and change processes in students if they merely reproduce knowledge, and that appears to be the line of initial training received.

\subsection{Learning Outcomes: Formal Convergence and Fictitious Digital Transformation}

Regarding learning outcomes, the data analysis shows that innovation has generally been reflected in a more formal development than digital (formal creation); its presence established in the official decree but its execution shrouded in indeterminate and generic formats with no reference to the meaning of digital innovation or how to construct and direct learning outcomes toward real situations.

Data processing has enabled us to verify that the UNESCO strategy is present in the cognitive field through the need to understand the use of ICTs and training in audio-visual and multimedia communication (know and develop innovation projects, know current references in innovation). It is also present in the collaborative use of ICTs in professional contexts (implement collaborative and coordinated teaching strategies), and in the capacity teachers must show for digital material production and for managing adverse situations with ICTs (identify learning problems and generate proposals).

However, these results do not necessarily allow us to affirm that the third level of digital creation has been achieved and that, furthermore, the use of the term innovation is not directly associated with the digitalisation of education. Analysis shows that the wording of curriculum frameworks is excessively generic and extremely compliant with regulations 
(is capable of obtaining, processing digital information) but the significance of digital knowledge and level of awareness and implementation is unknown. Achieving this level of digital creation requires all curricular elements (content, methodology, activities, assessment) to converge, which is not clear here, and there is an asymmetry regarding how digital culture is represented in the curriculum framework.

As for youth identity culture, beyond formal expression (reproducing the norm), there are few references to transferring to a more emotional and personal management sphere.

Regarding assessment, the most commonly-used mechanisms -content tests, tutoring, observing performance, individual reports, (few cases of) participation in forums and blogs, (also minor presence of) creation of portfolios and creation of specific assessment headingshighlight a timid attempt to transfer digitalisation to assessment (formal creation).

Analysing this category according to the UNESCO strategy (UNESCO, 2008, 2019) also shows that we are far from the profile of digital innovator and have not achieved the social and identity innovation mentioned in the MIL framework (UNESCO, 2011). Selfassessment, peer assessment and collaborative assessment are missing in order to generate reflections from the use of digital assessment tools.

\section{DISCUSSION AND CONCLUSIONS}

No studies on the incorporation of digital grammar in teacher training have been found, except for university strategic plans. However, the line of research initiated by HernándezHernández and Sancho-Gil (2020) opens up a wide range of possibilities for analysing the appropriation of this digital culture.

The aim of this paper was to verify the permeability of the international political agenda in regard to teacher training, and its specification in the initial teacher training regulatory framework. Results generally highlight the formal recognition of digital technology as a means of learning associated with initial teacher training. Analysis shows the existence of technological content, of activities leading to technology competencies, and of learning outcomes that follow the path set in regulations, although none of this confirms an educational transformation of digitalisation. Its mere presence is not leading to digital production (critical and individual), while digital innovation cannot be subsumed into the mere consumption or use of technological tools.

The paper acknowledges that innovation is indeterminate despite the fact that there are teaching dynamics that represent an approach towards digital innovation. However, transformation to a digital training model that would entail both a systematic approach and humanistic, educational development of technology has not yet occurred. This idea is key as it enables us to move forward with the need to replace the stagnant discourses that have shaped national curriculum frameworks with relational training systems under permanent construction.

This paper comes at a time when significant deficiencies in teacher training policy are becoming visible, deficiencies not so much related to a lack of equipment or the technocratic nature of technology, but with the lack of an educational definition of digital culture. 
An analysis of Master's teaching frameworks which highlights little innovation, superficial methodological changes, assessments impermeable to digital formats, and more descriptive than analytical content, highlights a problem at institutional level but with a clear pedagogical impact.

A highly advanced international initiative (UNESCO, 2008, 2011, 2019) has been in place for years, yet it has not been decoded by national (nor international) educational frameworks, despite its topicality and value demonstrated in other areas. This leads us to stress the fragility of institutional strategies and the neglect shown towards the organisation of training and attending to the educational needs of young people.

\section{ACKNOWLEDGEMENTS}

This paper is framed within the development of two national research projects: "CONNECT-ID. La identidad hiperconectada de la juventud y su percepción del tiempo en el ocio digital" [Hyperconnected identity of young people and their perception of time in digital pastimes] funded by Spain's Ministry of Science, Innovation and Universities (Ref. PGC2018-097884-B-I00) and "Identidades digitales en jóvenes hiperconectados: retos para el contexto familiar, social y escolar" [Digital identities in hyperconnected young people: challenges facing the family, social and learning context], funded by Regional Government of Castilla y León (Ref. SA038G19).

Funded by: Ministry of Science, Innovation and Universities, Spain

Funder Identifier: http://dx.doi.org/10.13039/100014440

Award: PGC2018-097884-B-I00

Funded by: Regional Government of Castilla y León, Spain

Funder Identifier: http://dx.doi.org/10.13039/501100014180

Award: SA038G19

\section{REFERENCES}

Aguaded, I., \& Marzal-Felici, J. (2021). La Educomunicación en España: Un reto urgente para la sociedad digital. Retrieved from https://www.edu-comunicacion.es/declaracion/

Alcolea, G., Reig, R., \& Mancina, R. (2020). Currículo de alfabetización mediática e informacional de la UNESCO para profesores desde la perspectiva de la Estructura de la información. Comunicar: Revista Científica de Comunicación y Educación, 62(28), 103-114. https://doi.org/ 10.3916/C62-2020-09

Bergdahl, N., Nouri, J., \& Fors, U. (2020). Disengagement, engagement and digital skills in technology-enhanced learning. Education and Information Technologies, 25, 957-983. https:// doi.org/10.1007/s10639-019-09998-w

Börnert-Ringleb, M., Casale, G., \& Hillenbrand, C. (2021). What predicts teachers' use of digital learning in Germany? Examining the obstacles and conditions of digital learning in special education. European Journal of Special Needs Education, 36(1), 80-97. https://doi.org/10 $.1080 / 08856257.2021 .1872847$

Cabero, J. (2004). Formación del profesorado en TIC. El gran caballo de batalla. Comunicación y pedagogía, 195, 27-31. Retrieved from https://bit.ly/3eFPla3 
Cabero, J., \& Martínez, A. (2019). Las Tecnologías de la Información y Comunicación y la formación inicial de los docentes. Profesorado. Revista de Currículum y Formación de Profesorado, 23(3), 247-268. https://doi.org/10.30827/profesorado.v23i3.9421

Cáceres, P. (2003). Análisis cualitativo de contenido: una alternativa metodológica alcanzable. Psicoperspectivas, 2(1), 53-82.

Castañeda, L. J., Salinas, J., \& Adell, J. (2020). Hacia una visión contemporánea de la tecnología educativa. Digital Education Review, 37, 240-268. https://doi.org/10.1344/der.2020.37.240 $-268$

Comission, E. (2017). DIGCOMP: A Framework for Developing and Understanding Digital Competence in Europe. Retrieved from https://n9.cl/qfcgr

Díaz-Herrera, C. (2018). Investigación cualitativa y análisis de contenido temático. Revista General de Información y Documentación, 28(1), 119-142. https://doi.org/10.5209/RGID.60813

Dujo, A. G. D., Vlieghe, J., Muñoz-Rodríguez, J. M., \& Martín-Lucas, J. (2021). Pensar la (teoría de la) educación, desde la tecnología de nuestro tiempo. Teoría de la Educación. Revista Interuniversitaria, 33(2), 5-26. https://doi.org/10.14201/teri.25432

Dussel, I. (2012). La formación docente y la cultura digital: métodos y saberes en una nueva época. In A. Birgin (Ed.), Más allá de la capacitación. Debates acerca de la formación docente en ejercicio (pp. 1-20). Paidós.

Egido, I. (2020). El acceso a la formación docente inicial en Europa: políticas e investigación. Revista Española de Educación Comparada, 35, 197-211. https://doi.org/10.5209/rced.63476

Espejo-Villar, L. B., Lázaro-Herrero, L., \& Álvarez López, G. (2020). Estudio del blended learning en el gobierno universitario español: tecnocracia digital versus conocimiento científico. Revista De Pedagogía, 72(3), 85-103. https://doi.org/10.13042/Bordon.2020.73343

European Comission. (2020). Digital education action plan 2021-2027: resetting education and training for the digital age. Retrieved from https://bit.ly/2QHd4yz

European Parliament. (2018). Education in the digital era: Challenges, opportunities and lessons for EU policy design (2018/2090(INI)). Retrieved from https://n9.cl/yhsf7

Eurydice. (2019). Digital Education at School in Europe. Eurydice Report. Publications Office of the European Union. Retrieved from https://bit.ly/3eI8lnb

Ferrari, A. (2013). DIGCOMP: A framework for developing and understanding digital competence in Europe. Joint Research Centre of the European Commission. Retrieved from https://publications.jrc.ec.europa.eu/repository/bitstream/JRC83167/lb-na-26035-enn.pdf

Forbes, C. (2017). Authentic friendship in the age of social media. Pacífica, 29(2), 161-174. https:// doi.org/10.1177/1030570X17715283

Goriunova, O. (2019). The Digital Subject: People as Data as Persons. Theory. Culture \& Society, 36(6), 125-145. https://doi.org/10.1177/0263276419840409

Hernández-Hernández, F., \& Sancho-Gil, J. M. (2020). Pensar la praxis del campo del currículo como un entramado rizomático de relaciones y derives. Revista e-Curriculum, 18(3), 1052 1068. https://doi.org/10.23925/18093876.2020v18i3p-1052-1068

INTEF. (2013). Marco Común de Competencia digital docente v 2.0. Retrieved from https://n9.cl/ b081

Lee, S. M., \& Trimi, S. (2021). Convergence innovation in the digital age and in the COVID-19 pandemic crisis. Journal of Business Research, 123, 14-22. https://doi.org/10.1016/j.jbusres .2020 .09 .041

Leite, C. (2019). Teaching, learning and research: An analysis of the academic and political agenda. Academic growth in higher education: Questions and answers (pp. 19-30). Brill Sense.

Mace, R. (2020). Reformulando lo ordinario: ciberespacio y educación. Teoría de la Educación. Revista Interuniversitaria, 32(2), 109-129. https://doi.org/10.14201/teri.22473 
Mahlow, C., \& Hediger, A. (2019). Digital transformation in higher education. Buzzword or opportunity? eLearn, 5(13). https://doi.org/10.1145/3329488/3331171

Marcelo, \& Vaillant, D. (2018). Hacia una formación disruptiva de docentes. 10 claves para el cambio. Narcea.

Mishra, P., \& Koehler, M. J. (2006). Technological pedagogical content knowledge: A framework for teacher knowledge. Teachers College Record, 108(6), 1017-1054.

Monteiro, A. R., \& Leite, C. (2021). Digital literacies in higher education: Skills, uses, opportunities and obstacles to digital transformation. RED. Revista Educación a Distancia, 21(65), 1-20. https://doi.org/10.6018/red.438721

Morris, T. H., \& Rohs, M. (2021). The potential for digital technology to support self-directed learning in formal education of children: A scoping review. Interactive Learning Environments. https://doi.org/10.1080/10494820.2020.1870501

Muñoz-Rodríguez, J. M., Torrijos-Fincias, P., Serrate-González, S., \& Murciano-Hueso, B. A. (2020). Entornos digitales, conectividad y educación: percepción y gestión del tiempo en la construcción de la identidad digital de la juventud. Revista Española de Pedagogía, 78(277), 457-475. https://doi.org/10.22550/REP78-3-2020-07

OECD. (2018). Effective Teacher Policies: Insights from PISA. Retrieved from https://n9.cl/zysp6

OECD. (2019). TALIS 2018 Results (Volume I): Teachers and School Leaders as Lifelong Learners. Retrieved from https://bit.ly/3eDN8vO

Pangrazio, L., \& Sefton-Green, J. (2021). Digital Rights, Digital Citizenship and Digital Literacy: What's the Difference? Journal of New Approaches in Educational Research, 10(1), 15-27. https://doi.org/10.7821/naer.2021.1.616

Prendes, M. P., Castañeda, L., \& Gutiérrez, I. (2010). Competencias para el uso de las TIC de los futuros maestros. Comunicar, 35, 175-182. https://doi.org/10.3916/C35-2010-03-11

Quesada-Serra, V., Rodríguez-Gómez, G., \& Ibarra-Sáiz, M. S. (2017). Planificación e innovación de la evaluación en educación superior: la perspectiva del profesorado. Revista de Investigación Educativa, 35(1), 53-70. https://doi.org/10.6018/rie.35.1.239261

Redecker, C., \& Punie, Y. (2017). European framework for the digital competence of educators: DigCompEdu. Publications Office of the European Union. Retrieved from https://bit.ly/3t0ZnaX

Sancho-Gil, J. M., Rivera-Vargas, P., \& Miño-Puigcercós, R. (2020). Moving beyond the predictable failure of Ed-Tech initiatives. Learning, Media and Technology, 45(1), 61-75. Retrieved from https://n9.cl/4jt35

Sung, Y. T., Chang, K. E., \& Liu, T. C. (2016). The effects of integrating mobile devices with teaching and learning on students' learning performance: A meta-analysis and research synthesis. Computers \& Education, 94, 252-275. https://doi.org/10.1016/j.compedu.2015.11.008

UNESCO. (2008). Competency Standards Modules. ICT Competency Standards for Teachers. Retrieved from https://n9.cl/b3zok

UNESCO. (2011). Alfabetización mediática e informacional.. Retrieved from https://bit.ly/3nxjg8u

UNESCO. (2019). Marco de competencias de los docentes en materia de TIC. Versión 3. Retrieved from https://bit.ly/3t0R4vN

UNESCO. (2020). Ensuring effective distance learning during COVID-19 disruption: guidance for teachers. Retrieved from https://n9.cl/z4am7

Williamson, B. (2019). El futuro del currículum. La educación y el conocimiento en la era digital. Morata.

Zabalza-Beraza, M. A., \& Zabalza-Cerdeiriña, M. A. (2010). Planificación de la docencia en la universidad. Elaboración de las Guías Docentes de las Materias. Narcea. 